\title{
Aircraft Mortgage in Indonesia: Alternative Object of Material Guarantee as a Debt Settlement
}

\author{
Annalisa Y, Murzal Zaidan, Mada Apriandi, Febrian, Nurhidayatuloh
}

\begin{abstract}
In the development of material law in Indonesia, it is known both registered objects and unregistered objects that by analogy, registered objects are categorized as immovable objects. In Indonesia, aircraft are being classified as a registered object that can be guaranteed in the form of the mortgage as a debt settlement. Along with the development of law and society, the mortgage regulations are only mentioned briefly in the Indonesian Law of Fiduciary and the Law of Notary Position which state that an aircraft can be guaranteed in the form of a mortgage. However, until recently, any particular regulations regarding aircraft mortgage in Indonesia are not yet available. This research is a normative study that uses historical, statute, and comparison approaches. The problems examined in this study: firstly, how the mortgage as a material guarantee institution in Indonesia is being regulated. Secondly, does the mortgage institution have the potential as an alternative object of material guarantee for aircraft? The result of the study shows that the regulations on aircraft mortgage in Indonesia still refer to the ones in the Indonesian Civil Code. Meanwhile, the institution that has the potential as an alternative object of material guarantee for aircraft is in the form of mortgage because an airplane is a registered object which is analogous to an immovable object. It can be concluded, therefore, that there is a weakness in aircraft mortgage stipulation in Indonesia which may create legal uncertainty and weaken the position of the creditor. Therefore, along with the development of the community and the existence of legal certainty, it is necessary to make an aircraft mortgage law immediately.
\end{abstract}

Key Words: mortgage; aircraft; material guarantee; debt settlement.

\section{INTRODUCTION}

In material law of Indonesia, it is generally known such as movable and immovable object classification.i Meanwhile, in customary law, there is land and not land rating.ii But in its development, it is known also registered and unregistered objects such as ship and aircraft as mentioned in Law No. 17 of 2008 concerning Shipping and Law No. 1 of 2009 concerning Aviation. Classification of registered objects for vessel and aircraft is business development in today's

Revised Manuscript Received on September 22, 2019.

Annalisa Y, Faculty of Law, Universitas Sriwijaya. annalisa_yahanan@yahoo.com

Murzal Zaidan, Faculty of Law, Universitas Sriwijaya.

Mada Apriandi, Faculty of Law, Universitas Sriwijaya.

Febrian, Faculty of Law, Universitas Sriwijaya.

Nurhidayatuloh, Faculty of Law, Universitas Sriwijaya. modern modes of transportation. The importance of classifying objects relates to the form of guarantee institution which will bind the object. The registered objective is analogous by Moch. Isnaeni as an immovable object.iii Thus registered aircraft is then similar to an immovable object which can be used as an object of material guarantee. The form of material guarantee in Indonesia has 4 (four) types, namely: iv 1. Pawn; 2. Mortgage; 3. Fiduciary, and 4. Underwriting Rights.

In the history of the development of the Civil Law in Indonesia, especially the collateral law, pawn, and mortgage (as regulated in Book II of Civil Code) are the inheritance rules of the Dutch Colonial era and still used until now as guidelines in the contract law (Book III of Civil Code). However, the mortgage rules for land as regulated in Book II of Civil Code are no longer valid due to the enactment of Law No. 4 of 1996 concerning Mortgage Rights. v Meanwhile, for movable and unregistered objects, a fiduciary is the right institution (Law No. 42 of 1999 concerning Fiduciary).

With the non-enactment of mortgage with the land as a collateral object as it is regulated by the Civil Code, it does not mean that the mortgage institution becomes lost or vanished from the Indonesian legal system. It still exists and lives so that it can be used as a material guarantee institution as stated in Law No. 17 of 2008 concerning Shipping, which explicitly states that registered ship can be guaranteed with a mortgage. Question will arise, what about guarantee institution for aircraft? What kind of potential alternative guarantee institution should it be?

An aircraft is one object that can be used as a guarantee of material. Of the four types of material warranties above mentioned, which guarantee institution has the opportunity to be an alternative of material guarantee object model? Based on the background above, there are several problems to discuss in this research, firstly, how should the regulation of mortgage as a material guarantee institution in Indonesia be? And secondly, does the mortgage institution have the potential to become an alternative material guarantee toward aircraft as debt settlement?

Until now, Indonesia does not yet have specific rules regarding material guarantee institutions for aircraft. In the development of the business world, especially in credit agreement as principal agreement, the material guarantee is needed to assure 
debt settlement due to the debtor defaults. The aviation industry in Indonesia is overgrowing and requiring high operational funds.vi For this purpose, aircraft can be used as collateral to creditors as debt settlement. However, because the guarantee institution for aircraft has not explicitly been regulated, it could weaken the position of creditors.

\section{LITERATURE REVIEW}

\section{A. Credit Agreement}

Credit is one of the bank's business activities in distributing funds to the public. Providing loan from bank to debtor is based on the credit agreement. The credit agreement contains convention on the rights and duties of each party between the bank and customer, which will be a law for the parties who make it. This forms a contractual relationship and places rights and duties against parties by the agreement together. In banking practice, the credit agreement is made in writing and the form of the standard contract.vii

Based on Article 1 point 11 of Law No. 10 of 1998 concerning Banking, credit is the provision of money or bills that can be equated with it, based on an agreement or loan agreement between the bank and another party that requires the borrowing party to settle the debt after a certain period of time with interest. Credit agreement in the bank raises an agreement between the debtor and the creditor so that the parties bear the obligation as a consequence of promises pledged based on the contract.viii The credit agreement is usually firmly agreed that if the debtor defaults, the creditor has the right to take part or all of the proceeds from the sale of the collateral property as a debt settlement.ix

Credit activity is a risky activity that it should be accompanied by guarantees since the economic and also trade development followed by the development of credit needs and the allocation of credit facilities requires a security assurance. $x$

Credit agreement in the bank is classified as nameless agreement. By Article 1233 CIVIL CODE, it will create a deal, so that on the shoulders of the parties lie a responsibility as a consequence of the agreement they agree in.xiThe credit agreement is obligatory. If it is not equipped with a material guarantee agreement to obtain collateral, the claim right is only positioned as a private right that is guaranteed by Article 1131 CIVIL CODE. If the creditor would get a better position not just as a concurrent creditor and by the prudential principle, it is necessary to make an exclusive guarantee agreement that a certain object belongs to the debtor (movable or immovable object) to be bound as collateral.

In the credit agreement, it creates an obligation that makes the parties bound to each other, so that this type of contract is classified as an obligatory agreement.xii The law focuses on the necessity to carry out its obligation.xiii Thus, if the credit agreement is followed by a material guarantee agreement, then the creditor is positioned as the preferred creditor who gets a settlement of the debt in the debtor defaults.xiv

For the benefit of the creditor (bank), the bank has imposed more massive underwriting requirements on access to mortgage credit (e.g., loan-to-value reductions (LTV) and rate of effort), and this has resulted in lower credit risk analysis outcomes, higher spreads and additional costs (often not fordable to the borrower).xv

Regarding business in the aviation industry, it certainly requires enormous funds in its operations. The debtor can submit a credit agreement by pledging an aircraft as a debt settlement if the debtor defaults. The price of expensive airplanes makes it almost impossible for airlines to buy planes in cash, so what can be done is a credit mechanism.xvi To help domestic airlines gain the trust of creditors in providing loans to national airlines, Indonesia has ratified the Cape Town Convention and its Protocol by Presidential Decree No. 8 of 2007. The convention known as Cape Town Convention 2001 is a convention formed in the framework of smooth financing transactions related to aircraft and aircraft engines. The Civil Aviation Act of 2009 incorporated the elements of the Convention and its Protocol in Chapter IX, from Article71 to 82. Ratification of this Convention and Protocol will support aircraft procurement for national airlines of Indonesia.xvii

\section{B. Object as Collateral for The Debt}

Credit is the largest source of income and profits for banks. Therefore, it is no exaggeration to say that the stability of a bank's business is strongly influenced by the success of their management of credit. Every implementation of a loan agreement with the bank is required to submit a guarantee that serves to provide confidence to the bank that the credit given to customers can be received back by the agreed conditions. As mentioned by Ross Cranston, "where the debtor has agreed to give a security interest in specific collateral to the creditor"...xviii

The guarantee functions to minimize the risks that may arise in each credit release due to the debtor's default. Regarding credit to prospective debtors, the bank must have confidence in the ability or ability to repay credit loans by the debtor.xix

Civil Law in Indonesia recognizes material and individual guarantees.xx The material guarantee is considered to be the safest that is borne by the bank in the form of movable objects (pawn or fiduciary), or immovable purposes (mortgage or mortgage rights). The guarantee is anything that is received by the creditor and submitted by the debtor to guarantee the debt.xxi Furthermore, according to Gerald G. Thanixxii said that "Collateral is something that values while the debtor has the transaction in order the secure debt. Without the involution of collateral, there would simply be a contract for loan or debt and an obligation to repay it".

\section{Mortgage Concept}

The definition of mortgages found in Article 1162 CIVIL CODE, which limits that "mortgages are material rights to immovable objects to take compensation from them for settlement of an agreement." Under the provisions of Article 1162 CIVIL CODE, it 
is stated that mortgages are material rights to immovable objects, for taking the settlement of fixed objects and also to receive compensation for a solution.

It can be said that the mortgage rights are born not from the engagement, but the material agreement as to the accessories (additional agreement), considering the mortgage is mentioned as a settlement. This means that the meeting has failed to be paid off voluntarily. Thus, it can be said that the role of the rights of mortgages as material rights is to cover the unrealized achievements of the debtor as the object of the engagement which is the principal or the primary legal relationship. However, even though it is just a substitute payment, it turns out that this pattern has become a mortgage figure to be the mainstay of the initial engagement. Engagement formed from the first agreement has already a general guarantee, as mentioned in Article 1131 CIVIL CODE.xxiii However, the comprehensive warranty has not provided power to the creditor, so an exclusive guarantee is needed in the form of a mortgage.

But on the one hand, it turns out that a mortgage is applied to movable objects in an Islamic bank, as stated by Ahmad Supriyadi.xxiv When viewed closely, an institute of sharia mortgages is in demand from the public in providing financing compared to the Islamic Bank, Cooperative Rural Banks and Sharia because they are not too burdened for customers with requirements that are too heavy as in Islamic banks, as long as they have a good value for the goods at the disposal.

\section{METHODOLOGY/MATERIALS}

Type of this research is normative legal research to explore the purpose of the law, the value of justice, the validity of legal rules, legal concepts, and legal norms. Normative legal analysis has the goal of producing arguments, theories, or ideas as prescription or answer to the problem at hand.xxv With the arguments and theories and concepts discussed, this study can offer an alternative model of material guarantee objects such as aircraft with a mortgage as collateral.

For this study to produce an accurate discussion, a statute approach is used related to material guarantees and credit agreements. Meanwhile, the old traditional method is used in the context of Civil Law in Indonesia, which is still guided by CIVIL CODE, especially Book III. Also, a conceptual and comparative approach is used with several countries related to the implementation of mortgage guarantees for aircraft.

The types and sources of legal materials used in this study are primary legal materials such as legislation, secondary materials such as books, journals, theses and dissertations and tertiary materials such as dictionaries and encyclopedias. The study examined using analysis of legal articles and legal approaches could answer the research problems.

\section{RESULTS AND FINDINGS}

\section{A. Setting Mortgage as Material Guarantee Institution in Indonesia}

The initial arrangement of a mortgage guarantee institution is in Article 1162 Civil Code, stating that: "a mortgage is a material right for immovable objects, to take compensation from it for settlement of an agreement."xxvi

Article 1162 Civil Code stipulates explicitly that the mortgage rights are categorized as material rights, with superior characteristics born as an accessory agreement which would be a pillar of weak personal reasons from the results of union with the obligatory agreement classified as the main agreement and then bring forth an engagement.

The definition of a mortgage in Civil Code, which is one and a half centuries old, is "a material right for immovable objects, to take compensation from it for the settlement of an agreement." The definition is focused on the object of material guarantee in the form of "land." But "land" is here in the sense of "registered land" as mentioned in Articles 506, 507 and 508 Civil Code. Whereas unregistered land, which in the colonial era was dominated by indigenous people, the Dutch colonial government created its guarantee institution, called "credit verb and."

By the background of the Civil Code, as mentioned above, only limited land that has been registered can be tied to a mortgage guarantee institution. If traced, it turns out the style that has been determined by the Civil Code actually since the beginning of the embryo the existence of registered objects (land) was already known in the age of one and a half centuries ago. Along with the development of time and the increase of national development which is focused on the economic field, it is necessary to provide substantial funds and strong guarantee institutions and be able to give legal certainty to interested parties. So that it is required to establish regulation on Mortgage Rights as an institution of collateral rights that can be charged on land. For this reason, Law No. 4 of 1996 concerning the Right to Underwrite Land and Objects Relating to Land. Thus, the mortgage arrangement whose object is an immovable object in the form of land, initially regulated in Book II of the Civil Code, changes its settings after the issuance of Law No. 4 of 1996 concerning the Right to Underwrite Land and Objects Relating to Land (Underwriting Law).

Mortgages as material rights, which will be used for reimbursement of an agreement, characterize that the mortgage right was not born because of the support he supported but was taken from the material agreement as his accessory considering the mortgage was mentioned as a settlement. This means that the engagement itself has failed to be repaid voluntarily. In other words, it can be stated that the role of mortgage rights as material rights is to cover the non-realization of achievement as an object of engagement that is positioned as its parent or its primary legal relationship. But this pattern makes the mortgage figure the mainstay of the initial commitment. The agreement 
formed from the main deal in it already has a general guarantee that is concluded in Article 1131 Civil Code.

Mortgages as collateral for immovable objects, determined by the legislators in the past one and a half centuries, are only focused on land. The reason, area, has a much higher economic value than moving objects. So, it is natural that the range of articles governing mortgages in the Civil Code is far more detailed than a pawn, which has around 70 items (Article 1162-1232 Civil Code).

In some countries, aircraft are movable property. However, not all regulations that apply to movable objects also apply entirely to aircraft. The plane as a moving object has a nationality (national and registration mark). xxvii Registration of domestic aircraft is regulated in the Chicago Convention of 1944xxviii in which all member countries of the International Civil Aviation Organization (ICAO) recognize the legal status of aircraft as movable objects that have specificity (sui generis). Almost all of the Chicago Convention provisions are adopted by the Aviation Law in Indonesia to implement the standard and recommended practices provided by ICAO. For this reason, the Republic of Indonesia issued the 2009 Civil Aviation Act, which aims to promote the development of Indonesian air transportation.xxix Also, in the Geneva Conventions of $1948, x x x$ it was stated that member states must recognize civil rights in aircraft which are categorized as movable objects but can be burdened with a mortgage toward a chattel mortgage.xxxi

International arrangements related to financing aircraft through the Cape Town Convention of 2001 constitute the Convention on International Interests in Mobile Equipment. The Cape Town Convention of 2001 created a uniform international legal framework to protect investors in aircraft objects. It provides an International Registration for creditors and debtors to register their security interests and develop a set of essential remedies in the event of debtor default.xxxii

Some countries, such as the Netherlands, Italy, and France in their national law, regulate aircraft as movable objects that have unique characteristics (sui generis). These three countries can be burdened with mortgages because they are analogous to ships, where a certain weight that is registered and has a nationality can be loaded with a mortgage. Based on the regulation, an aircraft as a moving object has a special legal status (sui generis) because an airplane has a registration sign and nationality which is listed in the register of aircraft for the benefit of public law and civil law.

Thus, if there is a reconstruction of the mortgage guarantee institution in Indonesia in the future (ius constituendum), it should be adjusted to the narrative: a mortgage is the material right of a registered object to take debt settlements in advance in an agreement.

\section{B. Aircraft Mortgages as Alternative Objects of Registered Material Guarantee}

Initially, the mortgage was regulated in the Civil Code, as mentioned earlier. But the object is only registered land.
After the issuance of the Underwriting Rights Act, the land security arrangement no longer refers to Civil Code but in the Underwriting Rights Act.

When the new classification of objects appears, actually it is not a strange thing. It's just that the shape of the variant of the purpose is widened, where initially what was registered was only limited to ground objects, then began to be known to other commercial objects that had a mobile nature (naturally moving objects). Because it has been registered in a general register, then in people's lives, registered object attributes become forward. For example, objects related to the current modes of transportation are strategic such as ship and aircraft.

With the issuance of the Underwriting Law, which regulates the object of material guarantee against the land, it does not mean that the mortgage guarantee institution disappears from the legal system in Indonesia. It's just that the object of mortgage guarantee institutions is no longer land, but it still exists, which targets are normatively registered vessels as discussed in the Shipping Law. The figure of the registered item is also included in the 2009 Aviation Act which mentions registered aircraft.

Mortgage stipulations outside Civil Code, contained in Law No. 17 of 2008 concerning Shipping (Shipping Law), which explicitly regulates ship mortgages as stated in Article 60 (1) of the Shipping Law, which states that: "ships that have been registered if pledged can use a mortgage guarantee institution."xxxiii

Thus it is time to determine firmly that a mortgage object is a registered object. This fact is indisputable, but it is a challenge considering the age of the mortgage as a material guarantee institution in the Civil Code is very old. Mortgage articles in Civil Code will not be able to accommodate collateral objects such as aircraft as registered objects, where their existence is far more complicated than land which according to Civil Code is classified as an immovable object. Moreover, airplanes, as a registered object, is technically very complicated. This is a tough challenge when elaborating on mortgage guarantees so that they can be used to burden aircraft.

Mortgage loses land as its object but gets new substitution object that is far more sophisticated and complex, namely in the form of a registered object such as a ship. Such stipulation has the potential to be used to burden aircraft. Meanwhile, the mortgage figure in the CIVIL CODE must be adjusted to achieve the appropriate posture to meet current and future technological advancements. This is a challenge that is not easy, considering that the national order of material law does not exist yet. As explained above, it can be ascertained that for the present and future periods, a mortgage object is a registered object.

The ship has been normatively confirmed, if guaranteed to use a mortgage, only limited to boats that have been registered. Based on Article 158 (2) Law No. 17 of 2008 concerning Shipping xxxiv It is stated that ships can be expressed by registrant officials and Ship's Transfer of 
Title, gross tonnage sizes of at least GT 7 (seven Gross Tonnage). Ship registration is carried out by making a registration certificate it is then recorded in the Indonesian vessel register, which is located as a general register. For ships that have been registered, the owner is given a gross for the registration certificate of the boat which functions as a proof of registration (can be seen on the ship's body). Every vessel registered in Indonesia is given a sign of Indonesian nationality, which makes the vessels legally used as a means of commercial transportation and gives birth to proof of ownership of the ship.

As mentioned above, explicitly in the Shipping Law, it is stated that only registered vessels can be burdened with mortgages. What about unregistered ships that are owned by many fishermen, who want to apply for bank loans? What will material guarantees be used by the bank to obtain collateral objects? While credit facilities may not be discriminated in getting loan funds from the banks. Moch. Isnaeni explained that to overcome this problem, the law has still been able to resolve with a solution by utilizing the fiduciary institution.

Starting from the description above, the ship is qualified as a registered object with a somewhat complicated procedure. This is also experienced mutatis mutandis and applies to aircraft gave that both are modern means of transportation that are widely used. After the issuance of Law No. 1 of 2009 concerning Aviation (Aviation Law), this rule is a master rule which will be used as a reference for further regulations which are more detailed in its description. Aircraft with registered object issues can be reviewed in the Republic of Indonesia Minister of Transportation Regulation PM 52 of 2018 concerning Civil Aviation Safety Regulations Section 47 concerning Aircraft Registration or Permenhub 52/2018. register civil aircraft, the Director-General records the registration of civil aircraft containing information about aircraft registered in Indonesia, including

- Registration number;xxxv

- Registration sign and national mark;

- Aircraft model according to the maker;

- aircraft serial number;

- name of aircraft owner;

- address of aircraft owner;

- Name of aircraft operator;

- Address of the aircraft operator;

- name and address of the lessor; the date of issuance of an aircraft registration certificate.

The purpose of registering an aircraft is to establish its legal position. Also, the aircraft registration is also related to nationality and flag issues. The public has a simple understanding that the occurrence of the registration process and recording in the general register by a country brings with it the emergence of nationalities for ships and aircraft. Moreover, the existence of Article 95 a (1) of the Criminal Code, which essentially states that "Indonesian aircraft are aircraft registered in Indonesia." As a positive law, it is natural to be used as a measure by the general public. With registration, it immediately brings about the emergence of aircraft nationalities.

The aircraft is very much surrounded with its international nuances as mentioned in Article 71 of the Aviation Law, alluding to the worldwide interest in aircraft objects, which reads: "Aircraft objects can be burdened with foreign investments arising from agreements giving security rights, binding agreement on the title reservation, and/or leasing agreement. "Implicitly Article 71 of the Aviation Law states material guarantee rights can be charged to aircraft. Mortgage gave birth to material right, have the opportunity to be operated as a means of binding apparatus as collateral.

\section{Application of Mortgage Institutions as Objects of Material Guarantee Toward Aircraft as a Registered Object for Settlement of Debt}

The appearance of registered objects has been found in several regulations, while the definite specific rules have not been made. The result is a problem, namely how the legal status of registered objects, while the position, in fact, has been advanced. To overcome such a legal vacuum, an attempt is made to apply the analogy to the provisions of immovable objects on registered objects. This is not very difficult considering the embryo of objects registered in the Civil Code has been known since one and a half centuries ago. The analogy is the fact that the mortgage applies to registered objects.

Ships and aircraft are strategic transportation facilities currently being used both nationally and internationally. In connection with that, to systematize the interests of Indonesian national law, the right choice of law for the guarantee is a mortgage. For this reason, it is necessary to elaborate mortgage rules in the Civil Code, a challenge for the realization of a modern mortgage guarantee institution. Furthermore, Chapter IX of the Aviation Law concerning International Interests of Aircraft Objects is one of the essential materials to be regulated in more detail and systematically, by synergizing mortgage principles in Civil Code (such as the principle of specialization, publicity, droit de suite, priority) that are still feasible used. Likewise, essential principles related to the world of aviation, such as those contained in one of the Cape Town Convention protocols needs to be comprehensively accommodated, so that a mortgage guarantee institution is established and in line with other countries.

Related to registered objects, it has started on the ship as a registered item as mentioned in the Shipping Law. Article 12 of the Flight Law No. 15 of 1992 concerning Aviation (revoked by Law No. 1 of 1992 concerning Aviation) has explicitly stated that an aircraft that has a registration mark can be charged a mortgage.

Even though the Aviation Law 2009 does not mention the use of mortgage on aircraft, it also does not provide a ban on it, so binding apparatus using a mortgage in the banking world has the potential to be

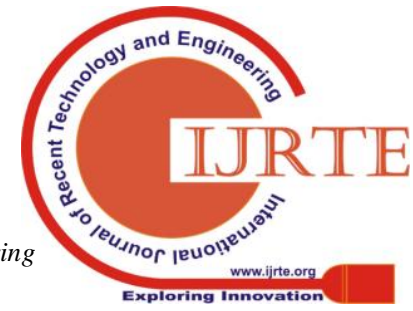


used and refers to Civil Code provisions. Even in Law No. 42 of 1999 concerning Fiduciary stated that the Fiduciary Shrimp Law does not apply to aircraft mortgages as mentioned in Article $3 \mathrm{c}$ which read: "This law does not apply to Mortgages on aircraft." Thus, it can be concluded that the Mortgage on an airplane does not use the provisions of the Fiduciary Law.

The appointment of the use of a mortgage for an aircraft which is an object of material guarantee is also stated explicitly in the Explanation of Article 15 (3) of Law No. 20 of 2014 concerning Notary Position, which gives the notary authority to make an aircraft mortgage deed.

The Aviation Law does not limit what forms of institutions should be used. However, it cannot be imposed with fiduciary charges because the debtor must submit the physical structure of the collateral object (aircraft) to the creditor (Bank), as also mandated by the Fiduciary Law.

The aircraft binding procedure using collateral in the form of a mortgage begins with a credit agreement as a principal agreement, in which the parties' agreement (bank and debtor) clause is entered into to carry out mortgage charges on an aircraft object as collateral for credit. At the same time as the agreement was signed, a power of attorney was approved to install the mortgage and the ability to sell.

Thus, for the normative period, it has now been stated that a mortgage is used to burden a vessel that has been registered as indicated in Law No. 17 of 2008 concerning Shipping. Likewise, the instructions mentioned in Law No. 42 of 1996 concerning Fiduciary and Law No. 2 of 2014 concerning Notary Position, as well as the Criminal Code that reinforces the use of mortgage charges on aircraft guarantee objects. Therefore, a one and a half-century mortgage guarantee institution-building need to be renovated by the demands of the industrial revolution 4.0. To support it all is not excessive if the mortgage guarantee institution that has been normatively used as stated in 4 (four) laws and regulations as mentioned above, gets more intense attention to realize a modern standard material guarantee institution.

Mortgage rules in the Civil Code have lagged far behind the current technological advances. This is a challenge in the future to immediately initiate the use of mortgage guarantees to burden aircraft.

\section{CONCLUSION}

From the description above, it can be concluded as follows:

- The initial embryo of regulation about mortgages as material guarantee institutions in Indonesia can be traced through Book II CIVIL CODE, which regulates the law of things. At that time the mortgage arrangement was only focused on land that was already registered, where land was classified as immovable property. Meanwhile, for the area that has not been disclosed, a guarantee in the form of credit verband is used. Along with the development of law and society, mortgage arrangements for land no longer use the rules in Book II Civil Code but have been replaced with Law No. 4 of 1996 concerning the Right to Underwrite Land and Objects Relating to Land. Mortgage arrangements are no longer in the interests of the land but are used for registered objects such as ships. Classification of registered objects is a development of the law of objects which has the potential to be used in the loading of a mortgage.

- The model of using the mortgage as an alternative guarantee of material for aircraft as settlement of debt is very appropriate. The reason is that aircrafts are registered objects which can be analogous to immovable objects, just as it is mentioned for ships as registered objects. Thus, mutatis mutandis it applies to aircraft which can be burdened with a mortgage. The regulation of aircraft mortgages in Indonesia does not yet have specific rules. Therefore, by the demands of the industrial revolution 4.0, it needs to be initiated so as to provide legal certainty in the field of collateral law, especially mortgage

\section{REFERENCES}

[1] American University of Beirut (2018). Badrulzaman, Mariam Darus, Mencari Sistem Hukum Benda Nasional (Alumni: Bandung, 1983)

[2] Perjanjian Kredit (Bandung: Citra Aditya Bakti, 1991)

[3] Bahsan, M, Penilaian Jaminan Kredit Perbankan Indonesia (Jakarta: Rejeki Agung, 2002)

[4] Convention on International Civil Aviation (Chicago, 1944)

[5] Cranston, Ross, Principles of Banking Law (Oxford: Clarendon Press, 1997)

[6] Fani Martiawan Kumara Putra, 'Surat Kuasa Memasang Hipotek Dalam Jaminan Hipotek Kapal Laut,' PERSPEKTIF, XVII (2012), 19

[7] Ferreira, Fernando A. F., Santos, Sérgio P, 'Comparing Trade-Off Adjustments in Credit Risk Analysis Of Mortgage Loans Using Ahp, Delphi And Macbeth', International Journal Of Strategic Property Manage, 20 (2016), 44-63

[8] Hadiati, Ms Mia and Martono, 'Contribution of Indonesia to International and Regional Civil Aviation', Journal of Electronics and Communication Engineering, 11 (2016), 46-64

[9] Honig, J.P., The Legal Status of Aircraft (The Hague: Martinus Nijhoff, 1956)

[10] Indrawati, Soewarso, Aspek Hukum Jaminan Kredit (Jakarta: Institut Bankir Indonesia, 2002)

[11] Isnaeni, Moch., Hipotek Pesawat Udara (Surabaya: PT. Revka Pertra Media, 2018)

[12] Hipotek Pesawat Udara (Seberkas Pelangi 4.0 Di Langit Euphoria Indonesia) (Surabaya: CV Revka Prima Media, 2018)

[13] Pengantar Hukum Jaminan Kebendaan (Surabaya: PT. Revka Pertra Media, 2016)

[14] Isnaeni, Moch, Pengantar Hukum Jaminan Kebendaan (Surabaya: PT. Revka Pertra Media, 2016)

[15] Kusmayan, Hazar, 'Penerapan Dan Permasalahan Eksekusi Pesawat Terbang Berdasarkan Hukum Acara Perdata Dalam Perjanjian Perawatan Mesin Pesawat,' Jurnal Bina Mulia Hukum, 1 (2016), 27

[16] Law No. 1 of 2009 on Aviation (Indonesia, 2009)

[17] Law No. 17 of 2008 on Shipping (Indonesia, 2008)

[18] Law No. 2 of 2014 on Amendment of Law No. 30 of 2004 on Notary (Indonesia, 2014)

[19] Martono, K, K. Mieke Komar K, Amalia, Prita, 'Implementation of The Cape Town Convention in Indonesia', In A Book Chapters Aviation Laws and Regulation Applicable in Indonesia (Jakarta: Pt. Grafindo Persada, 2017), P. 329

[20] Martono, Adya Paramita Prabandari; Wahyu Satrio Utomo; 'Indonesian Aviation Human Resources: An Evaluation,' Osr Journal of Applied Chemistry, 9 (2016), Pp 20-30

[21] Martono, Gunadi Ariawan And K., 'Current Indonesian Air Transportation,' Journal of Applied Chemistry, 9 (2016), 12-31.

[22] Martono, K, Pengantar Hukum Udara Nasional Dan Internasional, 1st Edn (Jakarta: Pt. Rajagrafindo Persada, 2007) 
[23] Marzuki, Peter Mahmud, Penelitian Hukum (Jakarta: Kencana, 2010)

[24] Ms Mia Hadiati And Martono, 'Contribution of Indonesia To International and Regional Civil Aviation', Journal of Electronics and Communication Engineering, 11 (2016), 46-64

[25] Mulya, Etty, 'Asas Keseimbangan Pada Perjanjian Kredit Perbankan Dengan Nasabah Pelaku Usaha Kecil', Jurnal Bina Mulia Hukum, 1 (2016), 37

[26] Rahman, Hasanuddin, Aspek-Aspek Hukum Pemberian Kredit Perbankan Di Indonesi (Bandung: Citra Aditya Bakti, 1995)

[27] Sari, Novi Ratna Sari, 'Komparasi Syarat Sahnya Perjanjian Menurut Kitab Undang-Undang Hukum Perdata Dan Hukum Islam', Jurnal Repertorium, Iv (2017), 81

[28] Sofwan, Sri Soedewi Masjchoen, Hukum Jaminan Di Indonesia: Pokok-Pokok Hukum Jaminan Dan Jaminan Perorangan (Yogyakarta: Liberty Offset, 1980)

[29] Hukum Jaminan Di Indonesia: Pokok-Pokok Hukum Jaminan Dan Jaminan Perorangan (Yogyakarta: Ugm Press, 2007)

[30] Hukum Jaminan Di Indonesia Pokok Pokok Hukum Jaminan Dan Jaminan Perorangan (Yogyakarta: Liberty Offset, 2007)

[31] Subekti, R Dan Tjitrosudibio, R, Kita Undang-Undang Hukum Perdata (Burgerlijk Wetboek) (Jakarta: Pradnya Paramita, 1980)

[32] Supriyadi, Ahmad, 'Implementation of Islamic Economic Principles About Mortgages', Qijis: Qudus International Journal of Islamic Studies, 2 (2014), 123

[33] Thain, Gerald G., 'A Basic Outline of The Law of Secured Transaction', In Seri Dasar Hukum Ekonomi, 4th Edn (Jakarta: Ellips Project, 1998), P. 15

[34] The Convention on International Reqognition of Right in Aircraft (Geneve, 1948)

i Sri Soedewi Masjchoen Sofwan, Hukum Jaminan Di Indonesia Pokok Pokok Hukum Jaminan Dan Jaminan Perorangan (Yogyakarta: Liberty Offset, 2007). Pp. 12-13.

ii Mariam Darus Badrulzaman, Mencari Sistem Hukum Benda Nasional (Alumni: Bandung, 1983). P. 15.

iii Moch. Isnaeni, Hipotek Pesawat Udara (Surabaya: Pt. Revka Pertra Media, 2018), P. 379.

iv Moch. Isnaeni, Hipotek Pesawat Udara. Note.

v Fani Martiawan Kumara Putra, 'Surat Kuasa Memasang Hipotek Dalam Jaminan Hipotek Kapal Laut,' Perspektif, Xvii.2 (2012), P. 19.

vi Gunadi Ariawan And K. Martono, 'Current Indonesian Air Transportation,' Journal Of Applied Chemistry, 9.10 (2016), Pp. 12-31.

vii Etty Mulya, 'Asas Keseimbangan Pada Perjanjian Kredit Perbankan Dengan Nasabah Pelaku Usaha Kecil', Jurnal Bina Mulia Hukum, 1.1 (2016), P. 37.

viii Moch. Isnaeni, Pengantar Hukum Jaminan Kebendaan (Surabaya: Pt.

Revka Pertra Media, 2016), P. 83.

ix Soewarso Indrawati, Aspek Hukum Jaminan Kredit (Jakarta: Institut

Bankir Indonesia, 2002), P. 8.

x Sri Soedewi Masjchoen Sofwan, Hukum Jaminan Di Indonesia:

Pokok-Pokok Hukum Jaminan Dan Jaminan Perorangan (Yogyakarta:

Liberty Offset, 1980), P.1.

xi Hasanuddin Rahman, Aspek-Aspek Hukum Pemberian Kredit Perbankan di Indonesia (Bandung: Citra Aditya Bakti, 1995), P. 175.

xii Moch. Isnaeni, Pengantar Hukum Jaminan Kebendaan (Surabaya: Pt. Revka Pertra Media, 2016). Note. P.83.

xiii Novi Ratna Sari, 'Komparasi Syarat Sahnya Perjanjian Menurut Kitab Undang-Undang Hukum Perdata Dan Hukum Islam', Jurnal Repertorium, Iv.2 (2017), P. 81

xiv Moch. Isnaeni, Pengantar Hukum Jaminan Kebendaan. Note. xv Sérgio P Ferreira, Fernando A. F., Santos, 'Comparing Trade-Off Adjustments In Credit Risk Analysis Of Mortgage Loans Using Ahp, Delphi And Macbeth', International Journal Of Strategic Property Manage, 20.1 (2016), Pp. 44-63.

xvi Hazar Kusmayan, 'Penerapan Dan Permasalahan Eksekusi Pesawat Terbang Berdasarkan Hukum Acara Perdata Dalam Perjanjian Perawatan Mesin Pesawat', Jurnal Bina Mulia Hukum, 1.1 (2016), P. 27.

xvii Prita Martono, K, K. Mieke Komar K, Amalia, 'Implementation Of The Cape Town Convention In Indonesia', In A Book Chapters Aviation Laws And Regulation Applicable In Indonesia (Jakarta: Pt. Grafindo Persada, 2017), P. 329.

xviii Ross Cranston, Principles Of Banking Law (Oxford: Clarendon Press,

1997), P.62.

xix Mariam Darus Badrulzaman, 1991, Perjanjian Kredit, Citra Aditya Bakti, Bandung, P. 81. xx Sri Soedewi Masjchoen Sofwan, 1997, Hukum Jaminan Di Indonesia: Pokok-Pokok Hukum Jaminan Dan Jaminan Perorangan, Ugm Press, Yogyakarta, Pp. 46-47.

xxi M. Bahsan, 2002, Penilaian Jaminan Kredit Perbankan Indonesia, Jakarta, Rejeki Agung, P. 148

xxii Gerald G. Thain, A Basic Outline Of The Law Of Secured Transaction, Seri Dasar Hukum Ekonomi 4 - Hukum Jaminan Indonesia, Jakarta, Ellips Project, 1998, Hlm. 15.

xxiii Moch. Isnaeni, Hipotek Pesawat Udara (Seberkas Pelangi 4.0 Di Langit Euphoria Indonesia), Cv Revka Prima Media: Surabaya, 2018, Pp. 185-186. xxiv Ahmad Supriyadi, Implementation Of Islamic Economicprinciples Aboutmortgages, Qijis: Qudus International Journal Of Islamic Studies, Volume 2, Issue 2, August 2014, P. 123.

xxv Peter Mahmud Marzuki, Penelitian Hukum, Jakarta: Kencana, 2010, P. 35.

xxvi R. Subekti Dan R. Tjitrosudibio, 1980. Kita Undang-Undang Hukum Perdata (Burgerlijk Wetboek), Pradnya Paramita: Jakarta, 1980.

xxvii J.P. Honig, The Legal Status of Aircraft. The Hague: Martinus Nijhoff, 1956, P. 58.

xxviii Convention On International Civil Aviation, Signed At Chicago On December 7th, 1944.

xxix Mia Hadiatiand Martono, Contribution Of Indonesia To Internationa And Regional Civil Aviation, Journal Of Electronics And Communication Engineering, Volume 11, Issue 4, Ver. Iv (Jul.-Aug .2016), Pp. 46-64 (P. 47).

xxx The Convention On International Recognition Of Right In Aircraft, Signed At Geneve On June 19th, 1948.

xxxi K Martono, Pengantar Hukum Udara Nasional Dan Internasional, 1st Edn (Jakarta: Pt. Rajagrafindo Persada, 2007), P. 262.

xxxii Mia Hadiatiand Martono, Contribution Of Indonesia To International And Regional Civil Aviation, Journal Of Electronics And Communication Engineering, Volume 11, Issue 4, Ver. Iv (Jul.-Aug .2016), Pp 46-64 (P.48)

xxxiii Republik Indonesia, Civil Aviation Act of 2009 (Indonesia: Menteri Hukum Dan Hak Asasi Manusia Republik Indonesia, 2009).

xxxiv Article 158 (2) Law No. 17 Of 2008 Concerning Shipping States That: "Ships That Can Be Registered In Indonesia, Namely: A. Vessels With Gross Tonnage Size Of At Least Gt 7 (Seven Gross Tonnage); B. Indonesian-Owned Vessels Or Legal Entities Established Under Indonesian Law And Domiciled In Indonesia; And C. Ship Owned By An Indonesian Legal Entity Which Is A Joint Venture Whose Majority Shares Are Owned By Indonesian Citizens ". xxxv Adya Paramita Prabandari,Wahyu Satrio Utomo, Martono, Indonesian Aviation Human Resources: An Evaluation, Osr Journal Of Applied Chemistry (Iosr-Jac), Volume 9, Issue 6 Ver. Ii (Jun. 2016), Pp. 20-30.

\section{AUTHORS PROFILE}

My name is Annalisa Y, currently I am affiliated with Faculty of Law, Universitas Sriwijaya. annalisa_yahanan@yahoo.com . my area of interest is law.

I am Murzal Zaidan, currently I am affiliated with Faculty of Law, Universitas Sriwijaya. My area of interest is jurisdiction and law.

My name is Mada Apriandi, and I am working with Faculty of Law, Universitas Sriwijaya.my area of interest is contributing in law.

My namen is Febrian, and I am part of Faculty of Law, Universitas Sriwijaya. My area of interest is law.

I am Nurhidayatuloh, and my affiliation is Faculty of Law, Universitas Sriwijaya. 